\title{
Pohjan pimiä puhuu moniäänisesti
}

\section{Tuula Hökkä: On kirkas Pohjan pimiä: Suomenkielistä runoutta 1800-luvulla. Helsinki: Studio Arkki, 2018, 228 s.}

Dosentti Tuula Hökkä on luonut uraansa Eeva-Liisa Manner -tutkimuksiensa ohella perehtymällä varhaiseen suomenkieliseen lyriikkaan. Tuoreimmassa, vuonna 2018 julkaistussa On kirkas Pohjan pimiä-teoksessa Hökkä kokoaa yhteen useita 1800-luvun lyriikasta kirjoittamiaan tekstejä tarjotakseen laajemman kuvan suomenkielisen runouden varhaiselta taipaleelta keskellä kansallisromanttista murrosta ja uuden kansakunnan luomistyötä. "Päällimmäisin vaikutelma on, että suomenkielisiä 1800-luvun runoilijoita on niukasti - puhumattakaan runoilijanaisista”, Hökkä lausuukin saatesanoissaan (7). Venyttäessään (kuten pitääkin) lyriikan rajoja kansanrunouteen, runonlaulantaan, arkkivirsiin, yksityisiin lyyrisiin sepityksiin, albumirunouteen, juhlalyriikoihin ja jopa runolliseen saarnaan, Hökkä kykenee piirtämään 1800-luvun meille säilyneestä traditiosta mielenkiintoisen kuvan, jossa naisrunoilijat nousevat merkittävään rooliin. Toki huomio ei ole yksinomaan suomenkielisessä runoudessa, sillä myös Isa Aspin kaksikielisen tuotannon ruotsinkielinen lyriikka saa teoksessa oman paikkansa.

Teoksessa tarkasteluun päätyvät aikansa merkittävimpänä runonlaulajana esiin nostetun ilomantsilaisen Mateli Kuivalattaren (1771-1846) laaja-alainen työ sekä hänen runoutensa Kantelettaren taustalla, taiteilijanimellä Kallio tunnetun oululaisen runoilija Samuli Kustaa Berghin (1803-1852) merkittävät mutta vähälukuiset runotyöt, kahdessa erillisessä luvussa käsiteltävä suomenkielinen albumirunous sekä Hökän tutkimusten kestoaiheet: Etelä-Savossa vaikuttaneen herätysjohtaja Margareta Högmanin (1786-1849) arkkivirret (sekä runollinen joulusaarna) ja kainuulaisen, aivan liian nuorena kuolleen Isa Aspin (1853-1872) nykyään tunnustettu runous. Etenkin luku Isa Aspista Aleksis Kiven merkittävänä aikalaisrunoilijana ja jopa Sapfoon rinnastettavana tekijänä nousee tässä valikoimassa esiin paitsi pituutensa - luku käsittää reilun kolmanneksen teoksen kokonaispituudesta -, myös sisältönsä eheyden ja kiinnostavuuden puolesta.

Parhaimmillaan Hökällä on artikkeleissaan kyky esittää asiat taitavasti historiallisessa kontekstissaan, vaikka pääpaino onkin usein itse runojen analyysissä. Isa Asp -luvussa tämä asetelma on kaikkein toimivimmassa muodossa, sillä historiallinen konteksti, Aspin henkilöhistoria, runojen konteksti ja runojen analyysi kulkevat siinä kiehtovasti rinnakkain. Vaikeammin paikkaansa teoksessa sen sijaan puolustaa Asp-lukua edeltävä luku "'Millon muistelet minua - millon?' - Runoluentaa 1995, 2018”, jossa Hökkä astuu teoreettisempiin 
saappaisiin ja esittelee de mannilaista lyriikan tulkintatapaansa sekä teoriassa että käytännössä. Tämä teoriapainotteinen luku erottuu teoksen muista luvuista. Analyysi on toki sinänsä arvokasta, joten olisi kenties ollut selkeämpää kirjoittaa se osaksi Kalliota käsittelevää lukua "Samuli Kustaa Berghin muotokuva 1978". Kyseinen luku jää niin ikään historiallisena kerrostumana irralleen muusta teoksen sisällöstä, sillä se pohjaa suoraan Hökän Kallio-matineassa Oulun päivillä 2.9.1978 pitämään esitelmään, joka on sittemmin julkaistu Kaltiossa (6/1978).

Juuri mainitun kaltaiset rakenteelliset seikat osoittavat teosta lukiessa, ettei kyseessä ole vertaisarvioitu tieteellinen antologia, vaan vapaamuotoisempi tekijän aiempien artikkeleiden, puheiden ja luentojen kokoelma, joka sisältää kerrostumia vuosikymmenten varrelta. Pahimmillaan tämä näkyy lukujen hajanaisuudessa, tekstin ajoittaisessa hengästyttävässä tyylissä, tietyssä toisteisuudessa ja osin luennonomaisessa rakenteessa, joissa runoanalyysi on paikoin hyvin pitkällistä ja raskasta. Parhaimmillaan laaja retrospektiivinen tausta puolestaan näkyy rakenteellisessa vapaudessa, eri tutkimustapoja ja -tyylejä edustavien lukujen välisessä vaihtelussa sekä ajoittaisessa esseemäisessä lähestymistavassa, joka on mielenkiintoista joihinkin alan muihin kenties enemmän toimitettuihin teoksiin verrattuna. Lukujen välisiä siltoja ja loppuyhteenvetoja olisin kuitenkin toivonut teokseen lisää. Lisäksi 1800-luvun kulttuurinhistoriaa vähemmän tuntevalle joitakin esiin nousevista termeistä ja tapahtumista, kuten vaikkapa loisvaimo, rahvaanrunous tai herännäisoikeudenkäynnit, olisi voinut selittää heti termien ensimmäisen maininnan yhteydessä.

Kokonaisuudessaan teos on sisällöltään arvokas ja mielenkiintoinen lisä 1800-luvun suomenkielisen lyriikan tutkimukseen. Erityisen kiinnostavia ovat Hökän luennat ja pitkälliset taltioinnit historiallisista dokumenteista, esimerkiksi litterointi Högmanin joulusaarnasta.

Olisikin sääli, jos tällaiset luentojen, puheiden ja artikkelikäsikirjoitusten sisällöt jäisivät tutkijoiden ja muiden aiheesta kiinnostuneiden lukijoiden ulottumattomiin. Tällaisenaan teos puolustaa ehdottomasti paikkaansa kirjallisuudentutkimuksessa.

Jyrki Korpua 